\title{
Strategi Pengembangan Kawasan Bumi Perkemahan KePurun Klaten Dengan Pendekatan ArsitekTUR EKOlOgis
}

\author{
Ayu Ratna Pertiwi ${ }^{1}$ \\ PROGRAM STUDI ARSITEKTUR \\ FAKULTAS TEKNIK \\ UNIVERSITAS SEBELAS MARET, SURAKARTA \\ email: apertiwi06@gmail.com \\ SRI YULIANI \\ PROGRAM STUDI ARSITEKTUR \\ FAKULTAS TEKNIK \\ PUSAT INFORMASI DAN PEMBANGUNAN WILAYAH (PIPW), LPPM \\ UnIVERSITAS SEBELAS MARET, SURAKARTA \\ AGUS HERU PURNOMO 3 \\ PROGRAM STUDI ARSITEKTUR \\ FAKULTAS TEKNIK \\ UNIVERSITAS SEBELAS MARET, SURAKARTA
}

\begin{abstract}
The development of Kepurun Camping Ground in Klaten with Ecological Architecture is motivated by the existing condition of the Camping Ground after being temporary shelter while the eruption of Mount Merapi in 2010 has a change function and can not longer be used for camping activities. Kepurun Camping Ground is the only camping ground in Klaten that organized by Kwartir Cabang Klaten, it is necessary to do the refunction and also the development of facility to reactivate the Kepurun Camping Ground as a place of camping activity in Klaten. The method used is the architectural method which is the essence of ecologycal architecture according to Heinz Frick and Kenneth Yeang according to the design of Kepurun Camping Ground. Then combine the essence of Architectural Ecology into the design. The strategy in essence design is the result of interaction between earth, nature, and natural potential existing of Kepurun Camping Ground is a camping facility, such as, hall, agrotourism area, and out bound area.
\end{abstract}

Keywords: Camping Ground, Ecological Architecture, Kepurun, Scout.

\section{PENDAHULUAN}

Bumi Perkemahan Kepurun Klaten merupakan satu-satunya Bumi Perkemahan yang dimiliki dan dikelola secara langsung oleh Kwartir Cabang Klaten. Bumi perkemahan ini berada di kaki Gunung Merapi dan memiliki banyak sekali potensi alam yang mendukung untuk dijadikan wadah kegiatan perkemahan. Namun sayang, pada tahun 2010 terjadi erupsi Gunung Merapi yang membuat Bumi Perkemahan Kepurun dijadikan lahan didirikannya
Hunian Sementara (Huntara) korban erupsi Gunung Merapi dan Bumi Perkemahan Kepurun mengalami alih fungsi sehingga tidak dapat lagi digunakan sebagai tempat berkemah. Pada tahun 2013 dilakukan pembongkaran terhadap hunian sementara pengungsi erupsi Merapi tersebut, namun hal itu belum dapat mengembalikan sepenuhnya fungsi Bumi Perkemahan Kepurun sebagai tempat berkemah, maka perlu dilakukan pengembalian fungsi serta pengembangan untuk mengaktifkan 
kembali Bumi Perkemahan Kepurun sebagai Bumi Perkemahan yang dikelola langsung oleh Kwartir Cabang Klaten.

Selain pengembalian fungsi, pengembangan Bumi Perkemahan Kepurun juga didasari oleh pengembangan yang telah dilakukan sebelumnya oleh beberapa Bumi Perkemahan di Indonesia. Salah satu contohnya adalah Bumi Perkemahan Cibubur yang saat ini telah berkembang menjadi kawasan bumi perkemahan dengan fasilitas pendukung seperti tempatibadah, mck, dapur dan dilengkapi dengan fasilitas pembelajaran non formal seperti taman lalu lintas, area out bound dll.

Mengingat letaknya yang sangat strategis pada jalur perhubungan regional, wilayah kota Klaten mempunyai potensi untuk berkembang sebagai kota transit. Sehingga untuk menunjang hal tersebut, maka perlunya pengembangan potensi dari sarana dan prasarana antara lain wisata alam yang memanfaatkan potensi alam sekitar yang masih asli dan kondisi permukiman penduduk yang masih tradisional menimbulkan suasana yang berbeda dengan suasana di perkotaan, potensi pendidikan non formal, yaitu pendidikan mengenai kepekaan terhadap alam dan lingkungan, kepemimpinan, kerjasama tim, dan lain-lain. Hal ini sesuai dengan Rencana Induk Pembangunan Kepariwisataan (RIPP) Kabupaten Klaten Tahun 2014-2019, yaitu pengembangan sistem pariwisata terpadu untuk jenis usaha pariwisata yang multi aktivitas dan multi produk, dalam hal ini adalah pariwisata berbasis alam yang mencakup aspek pendidikan lingkungan dan pendidikan kepramukaan secara terpadu. Di Kecamatan Manisrenggo Klaten khususnya di Bumi Perkemahan Kepurun ini memiliki view alam yang sangat indah karena lokasinya yang dekat dengan lereng Gunung Merapi.
Bumi perkemahan Kepurun berada di tapak yang masih sangat alami, lingkungan sekitarnya pun masih sangat asri dengan pepohonan rindang, udara yang bersih dan sejuk serta air yang jernih. Maka dari itu akan sangat sesuai jika penataan massa bangunan pada kawasan bumi perkemahan dirancang dengan konsep yang ekologis dengan memanfaatkan potensi alam lingkungan sekitar tanpa merusaknya dan menjaga kelestarian alam tapak. Konsep kawasan yang ekologis juga sangat unik untuk menarik minat pengunjung dan sangat mendukung fungsi kawasan bumi perkemahan sebagai sarana edukasi tentang alam dan juga sesuai dengan filosofi pramuka, yaitu cinta alam.

\section{METODE PENELITIAN}

Penelitian tentang kajian Strategi Pengembangan Kawasan Bumi Perkemahan Kepurun Klaten Dengan Pendekatan Arsitektur Ekologis ini dilakukan dengan tahapan dan metode sebagai berikut:

1. Tahap I, mengidentifikasi potensi dan kendala yang ada di kawasan Bumi Perkemahan Kepurun Klaten menggunakan metode studi lapangan, yaitu dengan melakukan survey dan pengamatan secara langsung ke lapangan, di Kepurun Klaten dan ke tempat yang dijadikan preseden.

2. Tahap II, mengidentifikasi kegiatan yang dapat dikembangkan dari kawasan Bumi Perkemahan Kepurun Klaten menggunakan metode observasi dari survey dan pengamatan yang dalaksanakan.

3. Tahap III, menganalisis penerapan teori arsitektur ekologis dan regulasi terkait menggunakan studi literature berupa buku dan jurnal mengenai Bumi Perkemahan dan Arsitektur Ekologis, literature tentang 
RUTRW, RURTK, dan RIPP Kabupaten Klaten.

4. Tahap IV, menentukan strategi perancangan untuk mengembangkan kawasan Bumi Perkemahan Kepurun Klaten.

\section{HASIL DAN PEMBAHASAN}

\subsection{Potensi dan Kendala di Bumi Perkemahan Kepurun Klaten}

Saat ini bumi perkemahan di Indonesia telah mengalami pengembangan baik dari fasilitas kegiatan utama maupun fasilitas penunjang. Sebagai salah satu contoh adalah Bumi Perkemahan Cibubur yang mana mengalami pengembangan berupa fasilitas penunjang kegiatan pramuka dan wisata sesuai dengan potensi yang dimiliki daerah Cibubur yaitu letaknya yang berada di tidak jauh dari kota besar seperti Jakarta,Bogor, Depok, Tangerang dan Bekasi ini sasaran pengunjungnyapun bertambah luas menjadi kantor-kantor dan perusahaan yang membutuhkan sarana untuk kegiatan outing karyawan, selain itu masyarakat di daerah perkotaan cenderung kekurangan tempat rekreasi yang bernuansa alami, oleh karena itu dilakukan pengembangan fungsi berupa kawasan outbound dan rekreasi keluarga dengan fasilitas tambahan berupa wisma penginapan, taman rekreasi, kawasan agrowisata dan agroindustri.

Begitu pula dengan Bumi Perkemahan Kepurun di Klaten yang memiliki potensi untuk dikembangkan karena letaknya berada di jalur perhubungan regional sehingga mempunyai potensi untuk berkembang sebagai kota transit. Selain itu Bumi Perkemahan Kepurun yang terletak di Kecamatan Manisrenggo berada di kaki Gunung Merapi sehingga memiliki potensi alam berupa lahan pertanian yang subur dan juga memiliki potensi view alam yang indah.

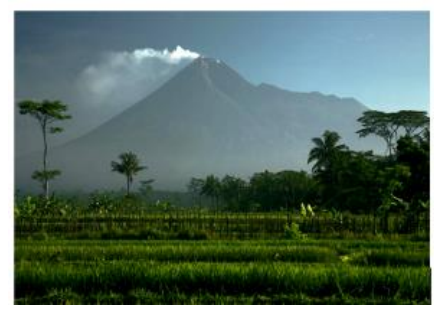

Gambar 1. View dari Bumi Perkemahan Kepurun Klaten

Hal ini juga didukung oleh Rencana Induk Pembangunan Kepariwisataan (RIPP) Kabupaten Klaten Tahun 2014-2019, yaitu pengembangan sistem pariwisata terpadu untuk jenis usaha pariwisata yang multi aktivitas dan multi produk, dalam hal ini adalah pariwisata berbasis alam yang mencakup aspek pendidikan lingkungan dan pendidikan kepramukaan secara terpadu.

Namun pada bulan November 2010 terjadi erupsi Gunung Merapi yang merusak rumah penduduk di sekitar lereng Gunung Merapi, kemudian Bumi Perkemahan Kepurun menjadi lahan dibangunnya hunian sementara (huntara) untuk para korban erupsi Gunung Merapi yang rumahnya telah hancur atau tidak layak huni akibat awan panas dari erupsi Gunung Merapi. Untuk itu lahan Bumi Perkemahan yang berupa tanah lapang dan area perkemahan didirikan bangunan sementara yang terbuat dari genting, baja ringan, anyaman bambu dan paving block.

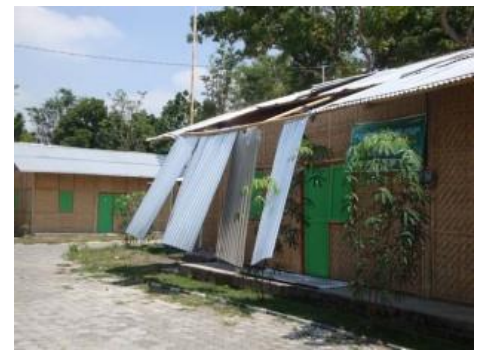

Gambar 2. Hunian Sementara di Bumi Perkemahan Kepurun Klaten

Hunian sementara (huntara) hanya digunakan oleh pengungsi sampai dengan tahun 2011 dan kemudian ditinggalkan begitu saja oleh 
penghuninya. Selama 2 tahun bumi perkemahan tidak dapat digunakan sama sekali akibat adanya huntara yang mangkrak tersebut. Selain itu huntara yang mangkrak juga disalahgunakan menjadi tempat minum-minuman keras, membolos dan tindakan asusila. Atas desakan masyarakat desa maka BPBD (Badan Penanggulangan Bencana Daerah) dan sukarelawan melakukan pembongkaran huntara pada tahun 2013, namun pembongkaran tersebut tidak lantas menyelesaikan masalah, banyak dari sarana dan prasana Bumi Perkemahan mengalami kerusakan, bahkan sudah tidak dapat berfungsi sama sekali akibat hunian sementara dan pembongkarannya tersebut, maka perlu dilakukan pengembalian fungsi serta pengembangan untuk mengaktifkan kembali Bumi Perkemahan Kepurun sebagai Bumi Perkemahan yang dikelola langsung oleh Kwartir Cabang Klaten.

\subsection{Kegiatan Yang Dapat Dikembangkan Dari Kawasan Bumi Perkemahan Kepurun Klaten}

Sesuai dengan fungsi utama dari Bumi Perkemahan Kepurun, bumi perkemahan memilikifungsi sebagai sarana kegiatan perkemahan kepramukaan, sehingga kegiatan utama yang diwadahi adalah kegiatan berkemah, dan kegiatan pendidikan kepramukaan seperti materi kepanduan, sejarah kepramukaan, tali temali, pioneering, semaphore, sandi, dan pengetahuan bertahan hidup di alam.

Selain kegiatan utama yang telah disebutkan di atas, terdapat juga kegiatan pengembangan yang sesuai dengan prinsip kegiatan pramuka yaitu cinta alam, pelatihan fisik dan juga rekreasi di alam terbuka. Untuk memfasilitasi kegiatan pengembangan tersebut maka akan dibuat fasilitas tambahan yang sesuai dengan kegiatan terkait, potensi yang dimiliki oleh Bumi Perkemahan Klaten dan juga sesuai dengan Rencana Induk Pembangunan
Kepariwisataan (RIPP) Kabupaten Klaten Tahun 2014-2019, yaitu pengembangan sistem pariwisata terpadu untuk jenis usaha pariwisata yang multi aktivitas dan multi produk, dalam hal ini adalah pariwisata berbasis alam yang mencakup aspek pendidikan lingkungan dan pendidikan kepramukaan secara terpadu, maka akan ditambahkan fasilitas berupa area agrowisata untuk mewadahi kegiatan cinta alam berupa kegiatan budidaya tanaman sayur dan buah, budidaya ikan air tawar dan peternakan sapi; fasilitas out bound untuk mewadahi kegiatan pengembangan dan pelatihan fisik.

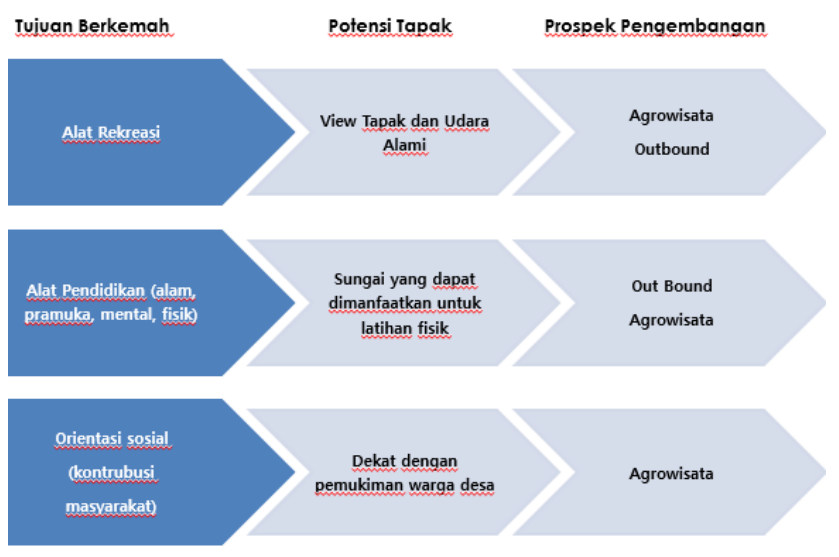

Gambar 3. Skema Pemetaan Kegiatan Perkemahan, Potensi Tapak, dan Pengembangan

\subsection{Penerapan Teori Arsitelktur Ekologis Dan Regulasi Terkait pada Kawasan Bumi Perkemahan Kepurun Klaten}

Bumi perkemahan Kepurun berada di tapak yang masih sangat alami, lingkungan sekitarnya pun masih sangat asri dengan pepohonan rindang, udara yang bersih dan sejuk serta air yang jernih. Maka dari itu akan sangat sesuai jika penataan massa bangunan pada kawasan bumi perkemahan dirancang dengan konsep yang ekologis dengan memanfaatkan potensi alam lingkungan sekitar tanpa merusaknya dan menjaga kelestarian alam tapak. 
Konsep kawasan yang ekologis juga sangat unik untuk menarik minat pengunjung dan sangat mendukung fungsi kawasan bumi perkemahan sebagai sarana edukasi tentang alam dan juga sesuai dengan filosofi pramuka, yaitu cinta alam.

Arsitektur Ekologis pada Kawasan Bumi Perkemahan Kepurun akan diterapkan pada:

a. Penentuan kegiatan kepramukaan dan pendidikan alam yang selaras dengan lingkungan Bumi Perkemahan.

b. Pengolahan kawasan yang bertujuan untuk pelestarian alam dan obyek pendidikan alam.

c. Penentuan tampilan kawasan yang berbasis arsitektur ekologis

Sesuai dengan prinsip-prinsip yang telah disampaikan oleh beberapa tokoh antara lain Heinz Frick dan Kenneath Yeang, dapat diambil beberapa poin penting dalam perancangan bangunan arsitektur ekologis yang akan diterapkan pada perancangan pengembangan kawasan Bumi Perkemahan Kepurun Klaten, antara lain:

a. Penyesuaian dengan lingkungan sekitar tapak

- Orientasi dan bukaan bangunan sesuai dengan kondisi klimatologi tapak

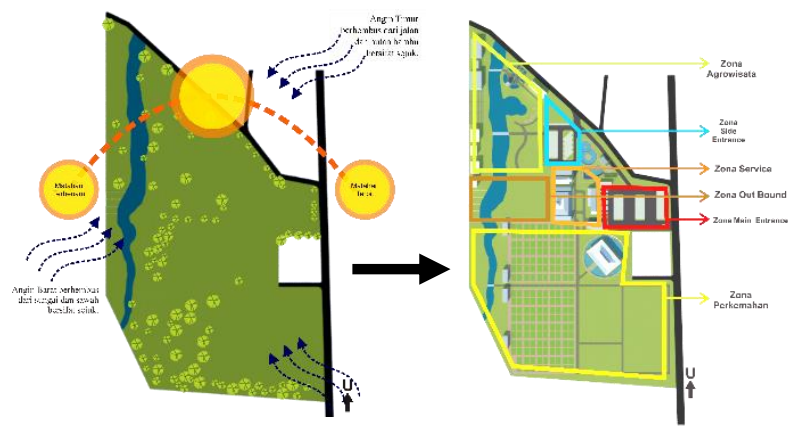

Gambar 4. Massa Bangunan Ditata Menyesuaikan Kondisi Klimatologis Tapak

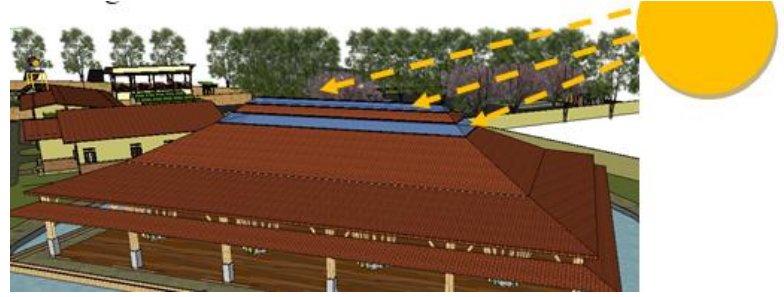

Gambar 5. Sky light pada atap bangunan sebagai jalan masuk cahaya alami

- Konfigurasi massa bangunan pada kawasan Bumi Perkemahan akan ditata menyesuaikan dengan bentuk tapak dan vegetasi eksisting yang telah ada. Pohon-pohon yang ada di site Bumi Perkemahan akan dimanfaatkan sebagai peneduh dan peredam kebisingan.

b. Pemeliharaan lingkungan sekitar tapak

- Air hujan di tapak bumi perkemahan selain akan jatuh dan diserap oleh tanah, akan ditampung di sumur resapan dangkal, untuk kemudian dimanfaatkan kembali untuk keperluan irigasi bumi perkemahan.

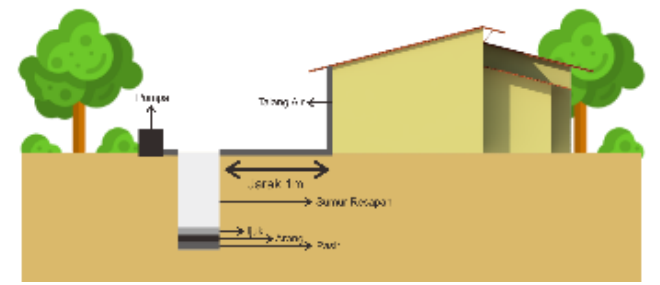

Gambar 6. Sistem Sumur Resapan Penampung Air Hujan

- Air hujan yang jatuh ke tanah juga akan ditangkap oleh lubang-lubang biopori yang tersebar di seluruh area tapak bumi perkemahan untuk mencegah genangan air yang terjadi saat curah hujan tinggi. Biopori juga memberi peran dalam peningkatan kualitas air tanah, organisme dalam tanah mampu membuat sampah menjadi mineralmineral yang kemudian dapat larut dalam air. Hasilnya, air tanah menjadi berkualitas karena mengandung mineral. 


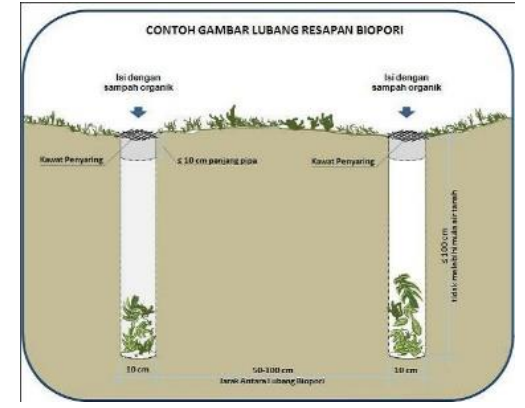

Gambar 7. Lubang Biopori

- Limbah padat yang berasal dari toilet (tinja) dan kotoran hewan ternak akan diolah menjadi biogas yang akan dimanfaatkan sebagai bahan bakar memasak.

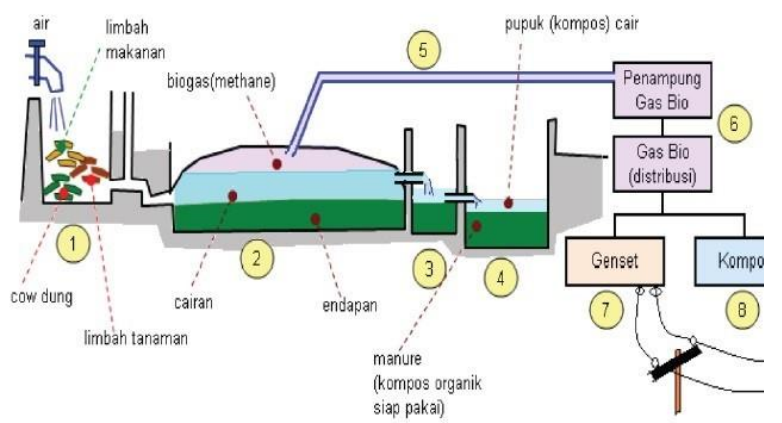

Gambar 8. Sistem Biogas

c. Pemanfaatan sumber daya alam di sekitar tapak

Perancangan kawasan Bumi Perkemahan Kepurun dilakukan dengan memanfaatkan potensi sumber daya alam sekitar tapak dengan cara menggunakan material bangunan yang berasal dari lingkungan sekitar, antara lain:

- Batu Bata dan Genting

Di Kepurun, Manisrenggo terdapat beberapa industry rumahan penghasil batu bata merah dan genteng.

- Pasir dan Batu

Lokasi Bumi Perkemahan, yaitu di Kepurun Manisrenggo Klaten berada dekat dengan Gunung Merapi dan sungai Woro, sehingga tersedia banyak material alami dari Gunung Merapi berupa pasir, batu kali, dan batu alam.
- Bambu

Di sebelah selatan lokasi Bumi Perkemahan terdapat hutan bambu yang dapat dimanfaatkan sebagai bahan bangunan alami.

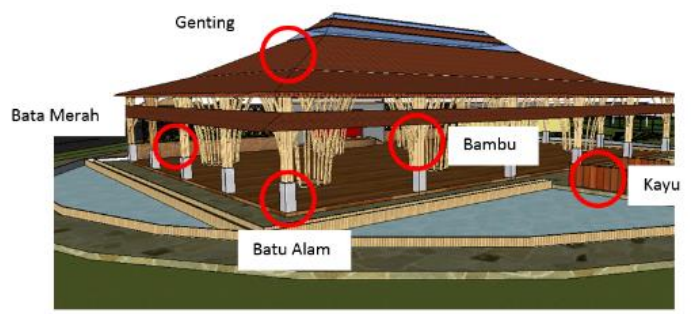

Gambar 9. Penggunaan material alam pada bangunan

Beberapa regulasi dan peraturan pemerintah Kabupaten Klaten terkait dengan perancangan pengembangan Bumi Perkemahan Kepurun sesuai dengan Peraturan Daerah Kabupaten Klaten Nomor 15 Tahun 2011 , antara lain: a. Mengolah tapak dengan ketentuan KDB $60 \%$ dan menyediakan RTH paling sedikit sebesar $20 \%$ dari luas tanah untuk nilai KDB $31 \%$ sampai dengan $70 \%$.

Luas lantai dasar yang boleh dibangun

$$
\begin{aligned}
& =\mathrm{KDB} \times \text { Luas Lahan } \\
& =60 \% \times 50.100 \mathrm{~m}^{2} \\
& =30.060 \mathrm{~m}^{2}
\end{aligned}
$$

b. Mengolah tapak dengan ketentuan KLB 0,8-4\%

- Luas lantai yang boleh

$$
\begin{aligned}
\text { dibangun } & =\mathrm{KLB} \times \text { Luas Lahan } \\
& =1.2 \times 50.100 \\
& =60.120 \mathrm{~m}^{2}
\end{aligned}
$$

- Jumlah lantai yang boleh dibangun =luas lt dasar $: \mathrm{KDB}$

$$
\begin{aligned}
& =60.120: 30.060 \\
& =2 \text { lantai. }
\end{aligned}
$$

c. Mengolah tapak dengan ketentuan Garis Sepadan Bangunan dengan aturan setengah dari lebar yang ada di sisi tersebut.

- 3,5 m pada sisi timur (Jalan Pramuka)

- 2,5 m pada sisi utara (Jalan Kampung Kepurun) 


\subsection{Strategi Perancangan Untuk Mengembangkan Kawasan Bumi Perkemahan Kepurun Klaten}

Pengembangan Kawasan Bumi Perkemahan Kepurun yang dirancang dengan pendekatan arsitektur ekologis mengacu pada pengaplikasian lima esensi arsitektur ekologis yang sesuai dengan perancangan obyek perancangan, yaitu penyesuaian dengan lingkungan sekitar tapak, pemeliharaan ligkungan sekitar tapak, dan pemanfaatan sumber daya alam sekitar tapak. Metode perancangan dan proses analisis yang dilakukan menghasilkan sebuah hasil berupa desain rancangan Pengembangan Kawasan Bumi Perkemahan Kepurun di Klaten dengan Pendekatan Arsitektur Ekologis sebagai berikut (lihat Gambar 14, 15, dan 16). Lokasi : Desa Kepurun, Kecamatan Manisrenggo, Kabupaten Klaten

Luas Lahan $\quad: 50.100 \mathrm{~m}^{2}$

Luas Bangunan $\quad: 22.300 \mathrm{~m}^{2}$ Fungsi : Sarana kegiatan perkemahan

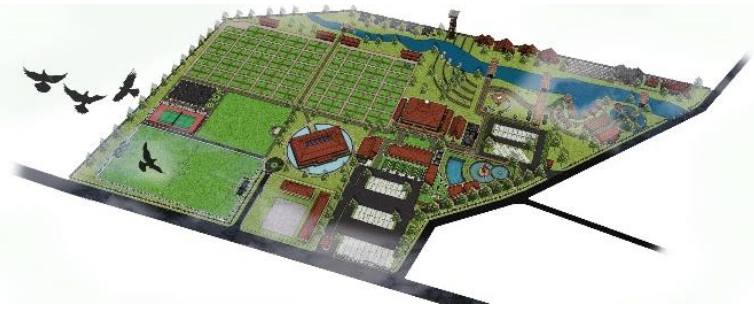

Gambar 10. Perspektif Mata Burung

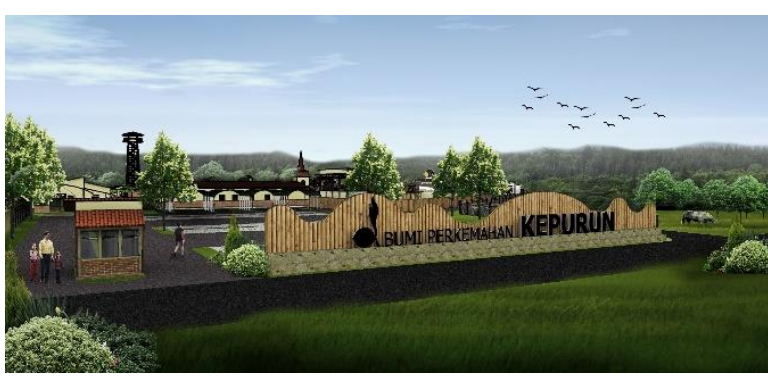

Gambar 11. Perspektif Entrance Kawasan

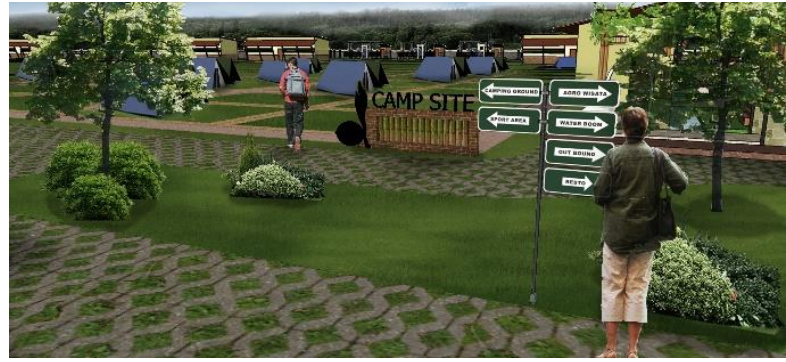

Gambar 12. Perspektif Area Campsite

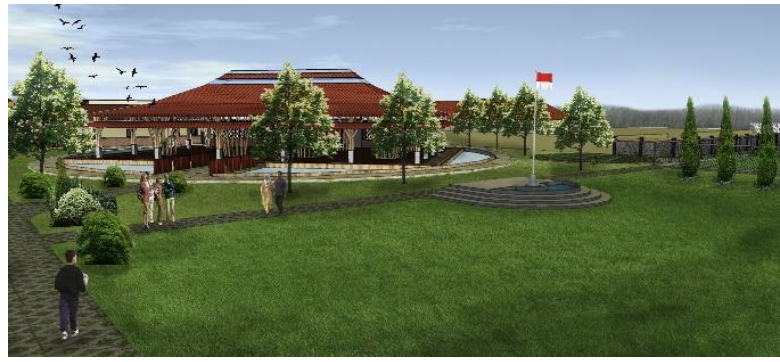

Gambar 13. Perspektif Eksterior Aula

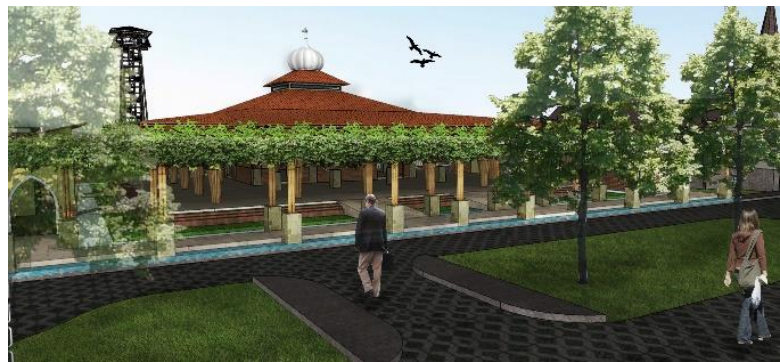

Gambar 14. Perspektif Eksterior Masjid

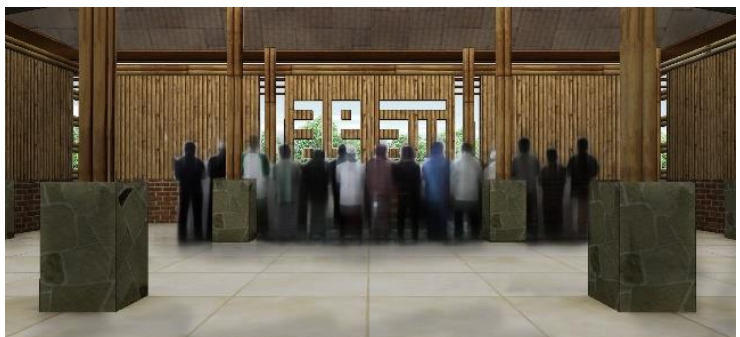

Gambar 15. Perspektif Interior Masjid 


\section{KESIMPULAN}

Bumi perkemahan di Indonesia saat ini telah banyak mengalami pengembangan, pengembangan tersebut disesuaikan dengan potensi dan juga kendala yang dimiliki oleh masing-masing daerah. Di Kabupaten Klaten khususnya di Kepurun memiliki potensi berupa lahan subur dan potensi view gunung merapi sehingga berpotensi dilakukan pengembangan berupa fasilitas agrowisata dan out bound yang juga sesuai dengan kegiatan kepramukaan yaitu kegiatan cinta alam dan kegiatan pelatihan fisik.

Untuk menjaga dan memaksimalkan potensi alam yang telah dimiliki oleh tapak, perancangan akan menggunakan pendekatan arsitektur ekologis yang memiliki prinsip membangun dengan memperhatikan keseimbangan lingkungan alam dan buatan dengan unsur utama manusia, bangunan, dan lingkungan. Sehingga akan menghasilkan rancangan desain yang mampu menjaga hubungan timbal balik antara lingkungan eksisting dan bangunan yang akan dirancang.

\section{REFERENSI}

Balitbang Kementerian Pendidikan Nasional, 2014, Pedoman Pendidikan Kepramukaan Pada Jenjang Pendidikan Dasar Dan Menengah. Jakarta: Kemdikbud.

Balitbang Kementerian Pendidikan Nasional 2014, Pedoman Penyelenggaraan Ekstrakurikuler Wajib Pendidikan Kepramukaan di Satuan Pendidikan, Jakarta: Kemendikbud.

Ching, F. D. K. 2008. Arsitektur:Bentuk, Ruang dan Tatanan. Erlangga;Jakarta

Fitriyanto, E., 2011. EKOLOGI DAN ILMU LINGKUNGAN | Ekofitriyanto's Blog [WWW Document]. URL https://ekofitriyanto.wordpress.com /2011/10/17/ekologi-dan-ilmulingkungan/ (accessed 11.7.16).

Frick H, FX Bambang Suskiyanto, (1998), Dasar-dasar Eko-arsitektur, Penerbit Kanisius, Yogyakarta.

Frick H, Tri Hesti Mulyani, (2006), Arsitektur Ekologis, Penerbit Kanisius, Yogyakarta.

Kementrian Pendidikan Nasional. 2010. Grand Design Pembangunan karakter bangsa 2010-2015. Jakarta: Kemdiknas.

Neufert, Ernst. Data Arsitek. Penerbit Erlangga. Jakarta

SK Kwartir Nasional : Nomor 178 Tahun 2010 Tentang Petunjuk Penyelenggaraan Organisasi Dan Tata Kerja Pusat Pendidikan Dan Pelatihan Gerakan Pramuka Tingkat Daerah.

SK Kwartir Nasional : Nomor 179 Tahun 2010 Tentang Petunjuk Penyelenggaraan Organisasi Dan Tata Kerja Pusat Pendidikan Dan Pelatihan Gerakan Pramuka Tingkat Cabang.

Takijoeddin M, 2010. Tertib Berkemah, Balai Penerbit Gerakan Pramuka, Jakarta

Tunasmedia Pustaka, 2010. Camp Planning, Balai Penerbit Gerakan Pramuka, Jakarta

Tunasmedia Pustaka, 2009. Petunjuk Penyelenggaraan Melintasi Halang Rintang, Balai Penerbit Gerakan Pramuka, Jakarta

Undang-undang Nomor 12 tahun 2000 tentang Kepramukaan

Yuliani Sri, 2013, Metoda Perancangan Arsitektur Ekologi, UNS Press, Surakarta. 